\title{
PENERAPAN MODEL PEMBELAJARAN PROBLEM BASED LEARNING DIPADU METODE DEBAT TERHADAP KEMAMPUAN BERARGUMENTASI
}

\author{
FadlilahSiti Firdauzi $^{1)}$, Rahma Widiantie ${ }^{2)}$, Handayani ${ }^{3)}$ \\ ${ }^{1}$ Pendidikan Biologi, FKIP, Universitas Kuningan \\ ${ }^{2}$ Pendidikan Biologi, FKIP, Universitas Kuningan \\ Email : rahma.widiantie @ uniku.ac.id \\ ${ }^{3}$ Pendidikan Biologi, FKIP, Universitas Kuningan \\ Email :handayani@uniku.ac.id
}
APA Citation: Firdauzi, F.S., Widiantie, R., \& Handayani, H. (2019). Penerapan Model Pembelajaran Problem Based Learning Dipadu Metode Debat Terhadap Kemampuan Berargumentasi. Quagga: Jurnal Pendidikan dan Biologi, 11(1), 49-54. doi: 10.25134/quagga.v11i1.1633.

Received: 25-01-2019

Accepted: 29-01-2019

Published: 29-01-2019

\begin{abstract}
Abstrak: Kemampuan berargumentasi siswa yang belum optimal dikarenakan proses pembelajaran yang dikembangkan lebih banyak menekankan pada pemberian materi dibandingkan memotivasi siswa dalam mengemukakan pendapat yang berkaitan dengan materi. Tujuan dari penelitian ini untuk menganalisis penerapan model pembelajaran Problem Based Learning (PBL) dipadu metode debat terhadap kemampuan berargumentasi pada materi pencemaran lingkungan. Penelitian menggunakan metod Non-equivalent (Pre-Test and Post-Test) Control Group Design. Populasi dalam penelitian ini adalah siswa kelas X dengan sampel sebanyak 30 siswa pada kelas eksperimen dan 30 siswa pada kelas kontrol melalui teknik pengambilan sampel cluster random sampling. Berdasarkan uji hipotesis terdapat perbedaan kemampuan berargumentasi pada kelas yang menerapkan model PBL dipadu metode debat dengan kelas yang menerapkan model PBL tanpa dipadu metode debat. Hasil kemampuan berargumentasi siswa menunjukkan bahwa kemampuan berargumentasi siswa kelas eksperimen lebih tinggi yaitu berada pada level 3 dengan kriteria cukup, sedangkan kelas kontrol berada pada level 2 dengan kriteria kurang. Peningkatan kemampuan argumentasi didukung dengan indeks n-gain pada kelas eksperimen yaitu 0,43 termasuk kriteria peningkatan sedang dan pada kelas kontrol yaitu 0,20 termasuk kriteria peningkatan rendah. Hal ini menunjukkan bahwa penerapan model pembelajaran Problem Based Learning dipadu metode debat dapat meningkatkan kemampuan berargumentasi siswa pada materi pencemaran lingkungan di kelas X SMA Negeri 1 Garawangi.
\end{abstract}

Kata kunci:Kemampuan Berargumentasi, Debat, Problem Based Learning

\begin{abstract}
Ability to argue students who are not optimal due to the learning process developed more emphasis on the provision of material than motivating students to express opinions related to the material. The purpose of this study was to analyze the application of the Problem Based Learning (PBL) learning model combined with the debate method on the ability to argue in environmental pollution material. The study used the Nonequivalent (Pre-Test and Post-Test) Control Group Design method. The population in this study were students of class $X$ with a sample of 30 students in the experimental class and 30 students in the control class through cluster random sampling sampling technique. Based on the hypothesis test there are differences in the argumentation ability of the class that applies the PBL model combined with the debate method with the class that applies the PBL model without the combined method of debate. The results of students' ability to argue showed that the ability to argue students in the experimental class was higher, namely at level 3 with sufficient criteria, while the control class was at level 2 with less criteria. The increase in argumentation ability is supported by the n-gain index in the experimental class, which is 0.43 including the moderate improvement criteria and in the control class which is 0.20 including the low improvement criteria. This shows that the application of the Problem Based Learning learning model combined with the debate method can improve students' ability to argue in environmental pollution material in class X of SMA Negeri 1 Garawangi.
\end{abstract}

Keywords: Ability to Argue, Debate, Problem Based Learning

\section{PENDAHULUAN}

Aplikasi ilmu pengetahuan memiliki peran penting dalam proses pembelajaran di sekolah.
Proses pembelajaran merupakan kegiatan pokok dalam mengembangkan ilmu pengetahuan yang dimiliki oleh siswa. Salah satu ilmu pengetahuan 
yang dipelajari di SMA adalah Biologi yang termasuk kedalam ranah IPA (Ilmu Pengetahuan Alam). Pembelajaran IPA merupakan pembelajaran yang didasarkan pada masalahmasalah sederhana yang terdapat pada kehidupan siswa sehari-hari. Berland (2008) menyatakan bahwa IPA merupakan cara memperoleh pengetahuan melalui kajian fenomena alam kemudian melakukan interpretasi terhadaphasil penelitian dan mengkomunikasikan hasilnya. Tuntutan kurikulum pembelajaran IPA menekankan siswa menjadi lebih aktif berinteraksi dengan guru dan sesama teman sekelasnya dalam proses pembelajaran di kelas. Biologi merupakan bidang studi yang harus dikuasai oleh siswa, karena konsep biologi dapat diterapkan siswa dalam memecahkan suatu masalah dalam kehidupan sehari-hari. Umum yang terjadi di lapangan, pembelajaran biologi di kelas lebih menekankan pada proses menghafal dalam bentuk pemberian materi. Siswa jarang difasilitasi dengan proses pembelajaran yang menuntut untuk mengemukakan pendapat atau ide pikirannya. Padahal proses mengeluarkan pendapat atau berargumentasi merupakan salah satu bentuk mengembangkan pikiran dan mengemukakan pengetahuan awal siswa terkait dengan materi yang dipelajari. Bentuk pembelajaran yang hanya mengemukakan bentuk pertanyaan konvergen cenderung membatasi siswa dalam mengembangkan pengetahuannya.

Oleh sebab itu, perlu dikembangkan cara untuk meningkatkan kemampuan berargumentasi siswa melalui pembelajaran biologi. Pritasari (2016) menyatakan bahwa argumentasi penting dikembangkan dalam pembelajaran biologi karena mampu meningkatkan pemikiran untuk menguji pemahaman siswa. Beberapa alasan pentingnya kemampuan berargumentasi diterapkan dalam pembelajaran Biologi yaitu:1) ilmuan menggunakan argumentasi dalam mengembangkan dan meningkatkan pengetahuan ilmiahnya; 2) masyarakat menggunakan argumentasi dalam perdebatan ilmiah; dan 3) siswa dalam pembelajaran membutuhkan argumentasi untuk memperkuat pemahamannya (Erduran et al., 2004). Alasan inilah yang mendorong pentingnya siswa memiliki kemampuan argumentasi yang baik.Salah satu bentuk pembelajaran yang dapat mengembangkan kemampuan argumentasi siswa adalah dengan pemberian masalah-masalah yang berkaitan dengan kehidupan sehari-hari. Melalui pemberian masalah siswa dapat melatih kemampuan berargumentasi dalam bentuk mencari solusi dari permasalahan.

Salah satu model pembelajaran yang dapat mengatasi masalah diatas adalah model PBL (Problem Based Learning) yang mengutamakan adanya masalah untuk menstimulus dan memfokuskan aktivitas belajar siswa melalui solusi atau ide yang dikemukakan siswa dalam rangka memecahkan masalah dalam kehidupan sehari-hari. Model PBL diharapkan dapat merangsang siswa untuk mengemukakan pendapatnya berdasarkan konsep yang diperoleh serta mampu mengambil keputusan dalam memecahkan masalah dalam kehidupan seharihari.

Metode debat merupakan metode pembelajaran yang menghadapkan siswa pada suatu permasalahan. Sanjaya (2009) dalam Arif (2016) menyatakan bahwa tujuan utama dari metode debat adalah untuk memecahkan suatu permasalahan, menjawab pertanyaan, menambah dan memahami pengetahuan siswa, serta untuk membuat suatu keputusan. Sehingga siswa akan terlibat intensif dan aktif karena siswa dituntut untuk berani dalam menyampaikan pendapat. Oleh karena itu, akan lebih baik jika model pembelajaran PBL dipadu dengan metode debat dimana kemampuan berargumentasi siswa terasah dengan baik.

Materi pencemaran lingkungan merupakan materi yang memuat permasalahan yang terjadi di lingkungan sekitar dan menjadi salah satu isu yang menjadi bahasan penting dalam kehidupan sehari-hari. Melalui materi pencemaran lingkungan diharapkan siswa dapat mengeluarkan solusi terbaiknya dalam bentuk argumentasi untuk memecahkan permasalahan yang berkaitan dengan pencemaran lingkungan yang terjadi di sekitar siswa.

\section{METODOLOGI PENELITIAN}

Penelitian dilaksanakan di SMA Negeri 1 Garawangi pada semester genap tahun Ajaran 2017/2018.Populasi dalam penelitian ini meliputi siswa kelas X SMA Negeri 1 Garawangi dengan sampel sebanyak 60 siswa yang diperoleh menggunakan teknik Cluster Random Sampling. Sampel terdiri kelas eksperimen dengan model pembelajaran PBL dipadu metode debat berjumlah 30 siswa dan kelas kontrol dengan model pembelajaran PBL berjumlah 30 siswa. Metode penelitian yang akan digunakan yaitu metode Quasy eksperimen dengan desain PreTest and Post-Test Control Group Design. Terdapat tiga instrumen pengambilan data yaitu 
Quagga: Jurnal Pendidikan dan Biologi

Volume 11, Nomor 1, Januari 2019

tes uraian, lembar observasi, danangket. Instrumen kemampuan berargumentasi digunakan untuk mengetahui kemampuan argumentasi siswa. Lembar observasi digunakan untuk mengamati dan menilai kemampuan siswa dalam berdebat pada saat proses pembelajaran di kelas eksperimen, serta angket digunakan untuk mengetahui respon siswa pada kelas eksperimen terhadap model pembelajaran yang diaplikasikan.

\section{HASIL DAN PEMBAHASAN}

a. HasilAnalisis Data

Instrumen tes uraian kemampuan berargumentasi berjumlah 15 soal dengan hasil uji validitas didapat 11 soal dinyatakan valid dan 4 soal dinyatakan tidak valid. Kemudian uji reliabilitas menunjukkan bahwa $\mathrm{r}_{\text {hit }}$ dari instrument tes uraian adalah 0,82 termasuk criteria sangat tinggi. Berdasarkan hasil analisis validasi, reliabilitas maka dapat disimpulkan bahwa dari 15 soal yang dianalisis terdapat 10 soal yang digunakan dan 5 soal lainnya tidak digunakan.

\section{1) Analisis Data TesUraian}

\section{a) Data Pretest}

Berdasarkan hasil pretest pada kelas eksperimen diperoleh nilai rata-rata siswa sebesar 30. Sedangkan untuk kelas kontrol diperoleh nilai rata-rata sebesar 26. Adapun level awal kemampuan berargumentasi pada kelas eksperimen dan kelas control dapat dilihat pada Gambar 1 berikut ini :

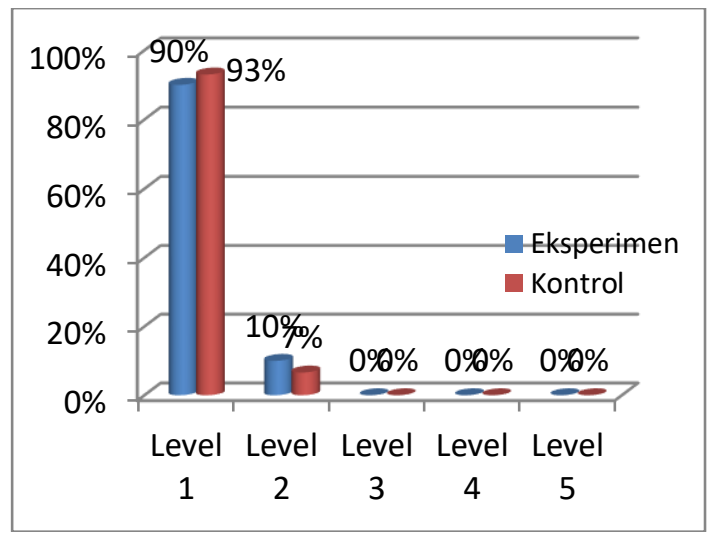

Gambar 1. Level Argumentasi Pretest

Berdasarkan gambar 1 tersebut dapat disimpulkan bahwa rata-rata kemampuan berargumentasi awal kelas eksperimen dan kontrol berada pada level 1 .

b) Data Posttest

Berdasarkan hasil posttest kemampuan berargumentasi nilai rata-rata kelas eksperimen diperoleh sebesar 60. Sedangkan untuk kelas
p-ISSN 1907-3089, e-ISSN 2651-5869

https://journal.uniku.ac.id/index.php/quagga

kontrol sebesar 39. Adapun level kemampuan berargumentasi pada kelas eksperimen dan kelas control dapat dilihat pada Gambar 2 berikut ini :

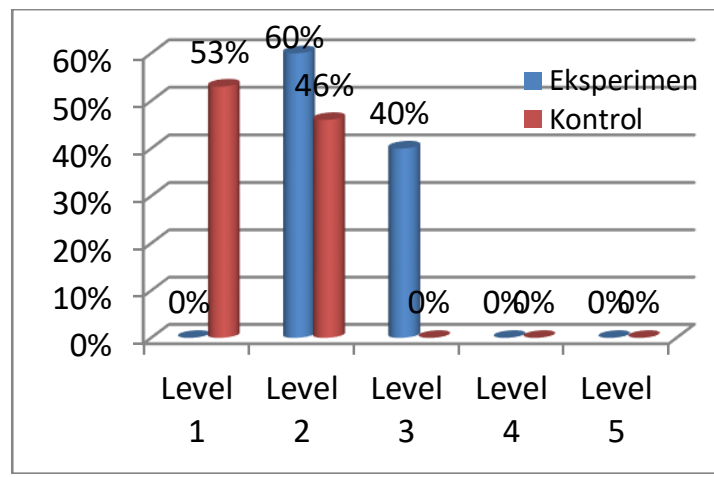

Gambar 2. Level Argumentasi Posttest

Berdasarkan Gambar 2 dapat diketahui bahwa rata-rata persentase level kemampuan berargumetasi kelas eksperimen lebih tinggi yaitu level 3 dibandingkan dengan kelas kontrol yaitu level 2.

2) Analisis Data Hasil Lembar Observasi

\begin{tabular}{ccc}
\multicolumn{3}{c}{ Tabel 1. Skor Kemampuan Debat Siswa } \\
\hline Aspek & Persentase & Keterangan \\
\hline Penguasaan & $3.3(82 \%)$ & Baik \\
Tema & $3.1(76 \%)$ & Baik \\
Ethos & $3.7(92 \%)$ & SangatBaik \\
Pothos & $3.8(95 \%)$ & SangatBaik \\
Logos & $\mathbf{3 . 5 ( 8 8 \% )}$ & SangatBaik \\
\hline Rata-rata
\end{tabular}

Berdasarkan Tabel 1 dapat diketahui bahwa rata-rata aspek debat setiap kelompok berada pada kategori sangat baik.

3) Analisis Data Angket

Hasil analisis angket diperoleh persentase respon positif $87,8 \%$ dan respon negatif sebanyak $12,8 \%$. Untuk lebih jelasnya dapat dilihat pada gambar 3 berikut ini :

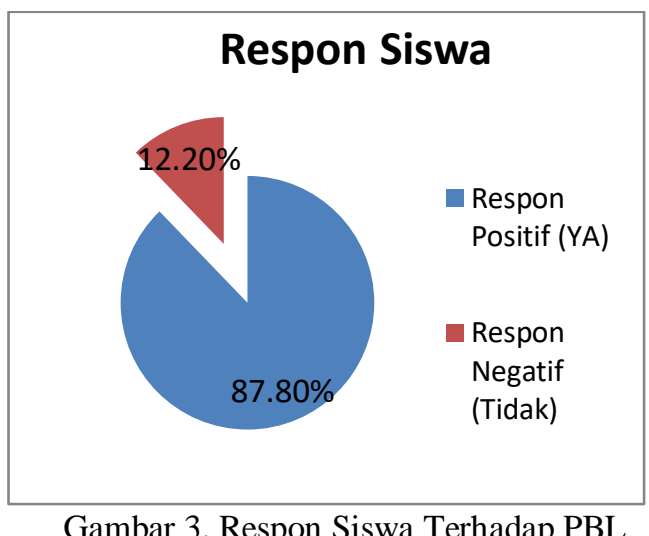

Gambar 3. Respon Siswa Terhadap PBL 
Quagga: Jurnal Pendidikan dan Biologi

Volume 11, Nomor 1, Januari 2019

b. Hasil Uji Hipotesis

1) Data Pretest

Tabel 2. Uji Hipotesis Data Pretest

\begin{tabular}{ccc}
\hline \multicolumn{2}{c}{ Uji Hipotesis } & \multirow{2}{*}{ Keterangan } \\
\cline { 1 - 2 } $\mathbf{t}_{\text {hitung }}$ & $\mathbf{t}_{\text {tabel }}$ & \\
\cline { 1 - 2 } 2,0 & 2,62 & $\begin{array}{c}\mathrm{H}_{\mathrm{o}} \text { diterima dan } \\
\text { Ha ditolak }\end{array}$ \\
\hline
\end{tabular}

Berdasarkan tabel 2 dapat diketahui bahwa hasil pretest menunjukkan tidak ada perbedaan kemampuan awal siswa antara kelas eksperimen dan kelas kontrol.

2) Data Posttest

\begin{tabular}{ccc}
\multicolumn{2}{c}{ Tabel 3. Uji Hipotesis Data Posttest } \\
\cline { 1 - 1 } \multicolumn{2}{c}{ Uji Hipotesis } & Keterangan \\
\cline { 1 - 2 } $\mathbf{t}_{\text {hitung }}$ & $\mathbf{t}_{\text {tabel }}$ & Ketan \\
\cline { 1 - 1 } 2,72 & 2,62 & $\begin{array}{c}\text { Ho ditolak dan } \\
\text { Ha diterima }\end{array}$ \\
\hline
\end{tabular}

Berdasarkan tabel 3 dapat diketahui bahwa hasil posttest kelas menunjukkan terdapat perbedaan kemampuan argumentasi siswa antara kelas eksperimen yang menggunakan model PBL dipadu dengan metode debat dengan kelas kontrol yang menggunakan model PBL tanpa metode debat.

3) Peningkatan Kemampuan Berargumentasi

Terdapat peningkatan antara nilai pretest dengan posttest yaitu $N$-gain pada kelas eksperimen sebesar 0,43yaitu kategori sedang, sedangkan nilai $N$-gain pada kelas kontrol sebesar 0,20yaitu kategori rendah. Hal tersebut menunjukkan peningkatan kelas eksperimen lebih tinggi dibandingkan dengan kelas kontrol.

\section{Pembahasan}

Berdasarkan hasil pretest menunjukkan bahwa terdapat kemampuan awal siswa yang setara pada kelas eksperimen dan kelas kontrol. Setelah menerapkan model pembelajaran PBL yang dipadu dengan metode debat pada kelas eksperimen dan menerapkan model PBL pada kelas kontrol, selanjutnya dilaksanakan posttest pada kedua kelas tersebut. Berdasarkan hasil uji $\mathrm{t}$ terdapat perbedaan kemampuan berargumentasi yaitu kemampuan berargumentasi kelas eksperimen lebih tinggi dibandingkan dengan kelas kontrol. Hal tersebut terjadi karena kelas eksperimen menerapkan model pembelajaran PBL yang dipadu dengan metode debat dapat merangsang rasa ingin tahu siswa untuk memecahkan permasalahan sehingga siswa dapat menyalurkan ide, gagasan, pendapat, serta mempertahankan atau menyanggah pendapat
p-ISSN 1907-3089, e-ISSN 2651-5869

https://journal.uniku.ac.id/index.php/quagga

siswa lain. Hasil tersebut sesuai dengan penelitian yang dilakukan oleh Afisha (2015) yang menyatakan bahwa dengan menggunakan pembelajaran PBL siswa mampu menemukan dan mencari sumber serta fakta. Penelitian tersebut didukung oleh Sari (2018) yang menyatakan bahwa dengan menerapkan metode debat dapat meningkatkan konsep pembelajaran siswa karena siswa secara bebas dapat menuangkan ide dan gagasan siswa serta mempertahankan dan menyanggah pendapat di depan kelas.

Berdasarkan hasil posttest level kemampuan berargumentasi siswa kelas eksperimen berada pada level 3 dengan kriteria cukup. Level tersebut membuktikan bahwa kelas eksperimen mampu memberikan pendapat yang mengandung sedikit sanggahan, namun belum mencapai level 4 dan level 5 karena siswa belum mampu memberikan data pendukung dan sanggahan yang banyak.Sedangkan kelas kontrol berada pada level 2 dengan kriteria kurang.Level tersebut membuktikan bahwa kelas kontrol belum mampu memberikan pendapat yang mengandung sanggahan, ini berarti kelas kontrol belum mampu mencapai level 3, level 4 dan level 5 karena kelas kontrol hanya menerapkan model pembelajaran PBL tanpa dipadukan dengan metode debat.

Hasil peningkatan tersebut juga didukung oleh lembar observasi kemampuan debat. Hasil analisis skor kemampuan debat siswa pada aspek penguasaan tema berada pada kriteria baik, hasil tersebut berarti siswa sudah memahami permasalahan atau persoalan yang akan didebatkan.

Aspek ethos atau kemampuan berkomunikasi untuk meyakinkan siswa lain. memiliki persentase sebanyak $76 \%$ dengan kriteria baik, ini berarti siswa sudah mampu berkomunikasi untuk meyakinkan siswa lain. Pada aspek pothos atau kemampuan berbicara memiliki persentase sebanyak $92 \%$, ini berarti kemampuan berbicara siswa tinggi karena siswa mampu membawa suasana pendengarnya kedalam pendapat yang disampaikan melalui gaya bicara yang dimiliki. Sedangkan pada aspek logos atau kemampuan menyampaikan imbauan secara logis memiliki persentase sebanyak 95\%, ini berarti siswa mampu memberikan bukti atau contoh berdasarkan materi dan menyampaikan pendapatnya dengan masuk akal yang sesuai dengan logika atau benar menurut penalaran sehingga pendapat tesebut dapat dicerna dan diikuti oleh pendengar. 
Berdasarkan hasil tersebut, penerapan metode debat dapat membantu siswa dalam meningkatkan kemampuan berargumentasi. Hal ini sesuai dengan pendapat Ismail (2008) dalam Arif (2016) bahwa tujuan penerapan metode debat adalah untuk melatih siswa berargumen yang kuat untuk memecahkan suatu permasalahan kontroversial dan memiliki sikap demokratis serta saling menghormati setiap pendapat yang berbeda. Selain itu menurut Nurchabibah (2011) menyatakan bahwa dengan menggunakan metode debat, menjadikan siswa lebih antusias untuk memberikan pendapat, menanggapi, mempertahankan pendapatnya, dan menyanggah pendapat.

Peningkatan kemampuan berargumentasi kelas eksperimen lebih tinggi dibandingkan dengan kelas kontrol. Hal tersebut karena selama proses pembelajaran siswa dituntut untuk menyampaikan, mempertahankan, dan menyanggah pendapat siswa lain yang disertai dengan contoh atau bukti yang nyata sehingga pembelajaran di kelas lebih aktif dan kritis dalam memecahkan permasalahan yang diberikan. Hal tersebutdidukungoleh Mika (2013) dengan menerapkan debat dapat meningkatkan keterampilan berargumentasi karena siswa mampu memperluas kapasitas penalaran dan mampu memprediksi sanggahan sebagai kunci untuk membangun argumen yang paling persuasif.

Respon siswa terhadap penggunaan PBL yang dipadu metode debat didapat respon positif terhadap penggunaan model PBL yang dipadu metode debat pada saat proses pembelajaran yang telah dilakukan. Sebagian besar siswa meyatakan bahwa senang mempelajari materi pencemaran lingkungan dengan menggunakan model PBL dipadu dengan metode debat sehingga siswa lebih mudah memahami materi dan mampu meningkatkan kemampuan berargumentasi.

\section{SIMPULAN}

Berdasarkan hasil uji $\mathrm{t}$ terdapat perbedaan kemampuan berargumentasi siswa yang menerapkan model pembelajaran PBL dipadu dengan metode debat yaitu kelas eksperimen dengan yang menerapakan model pembelajaran PBL yaitu kelas kontrol. Hasil kemampuan berargumentasi siswa kelas eksperimen lebih tinggi yaitu berada pada level 3 dengan kriteria cukup dibandingkan dengan kelas kontrol berada pada level 2 dengan kriteria kurang. Hal ini didukung dengan hasil indeks n-gain yang didapat pada kelas eksperimen yaitu 0,43 termasuk kriteria peningkatan sedang dan hasil indeks $n$-gain kelas kontrol yaitu 0,20 termasuk kriteria peningkatan rendah. Berdasarkan hasil analisis data dapat disimpulkan bahwa model pembelajaran PBL yang dipadu metode debat dapat meningkatkan kemampuan berargumentasi siswa. Hal tersebut karena model pembelajaran PBL yang dipadu metode debat dapat menstimulasi kemampuan berargumentasi siswa dengan cara merangsang rasa ingin tahu siswa untuk memecahkan permasalahan sehingga siswa dapat secara bebas menyalurkan ide, gagasan, pendapat, serta mempertahankan atau menyanggah pendapat.

\section{REFERENSI}

Afisha, M. Helen. 2015. Pengaruh Model Problem Based Learning terhadap Kemampuan Berargumentasi dan Hasil Belajar Siswa. [Artikel]. Universitas Lampung. Tersedia: download.portalgaruda.org/article.php. Diaksespadatanggal 25 Februari 2018

Arif, Muhammad. 2016. Peningkatan Kemampuan Bertanya Melalui Metode Debat Aktif Siswa Kelas VIII D SMP N 2 Banguntapan Bantul. E-Jurnal Prodi Teknologi Pendidikan Vol. V Nomor 5 Tahun 2016. FKIP Universitas Negeri Yogyakarta, Yogyakarta. Diakses pada tanggal 17 Mei 2018

Berland, L. Khun. 2008. Understanding The Composite Practice That Forms When Classrooms Take Up The Practice of Scientific Argumentation. Graduate School of Northwestern University: Disertasi Doktor. Diakses pada tanggal 3 Maret 2018

Erduran, S. et al,. 2004. Tapping into Argumentation: Developments in the Application of Studying Science Discourse. [Online] Science Education, hlm. 1-25. Tersedia: https://www.intersciencewiley.com. Diakses pada tanggal 3 Maret 2018

Mika, Nakano danShun'ichiMaruno. 2013. The Effect Of Debate Training On Argumentation Skills: The Developmental Process For Japanese College Students. Studies for the Learning Society. Volume 3: Issue 1-2: 2013: ISSN 17367107.Diakses pada tanggal 30 Agustus 2018 
Quagga: Jurnal Pendidikan dan Biologi

Volume 11, Nomor 1, Januari 2019
p-ISSN 1907-3089, e-ISSN 2651-5869

https://journal.uniku.ac.id/index.php/quagga

Nurchabibah. 2011. Keefektifan Metode Debat Aktif Dalam Pembelajaran Diskusi Pada Siswa Kelas X Sman 1 Kutowinangun. Skripsi. Fakultas Bahasa dan Seni Universitas Negeri Yogyakarta, Yogyakarta.

Pritasari, P.R., Dwiastuti. S., Probosari. R.M. 2016. Peningkatan Kemampuan Argumentasi melalui Penerapan Model Problem Based Learning pada Siswa Kelas $X$ MIA 1 SMA Batik 2 Surakarta Tahun Pelajaran 2014/2015. [Online]. Jurnal Pendidikan Biologi. Vol. 8 (1): 1-7 Tersedia:

https://www.researchgate.net/publication/ 316380967. Diakses pada tanggal 28 Februari 2018

Sari, Andi Nurindah. 2018. Pengaruh Teknik Debat Terhadap Keterampilan Berbicara Siswa Kelas X SMA Negeri 7 Pinrang Kabupaten Pinrang. Skripsi. Program Sarjana Pendidikan. Fakultas Bahasa dan Sastra. Universitas Negeri Makassar. Diakses tanggal 20 Juni 2018

Sugiyono. 2016. Metode Penelitian Pendidikan: Pendekatan Kuantitatif, Kualitatif dan $R \& D$. Bandung : Alfabet 